\title{
Identifikasi Aksesibilitas Difabel pada Mushalla Mall Panakkukang Kota Makassar
}

\author{
*Mayyadah Syuaib ${ }^{1}$, Rohana ${ }^{2}$ \\ ${ }^{1}$ Jurusan Arsitektur, Fakultas Teknik, Universitas Islam Negeri Makassar, Indonesia \\ ${ }^{2}$ Jurusan Arsitektur, Fakultas Teknik, Universitas Muhammadiyah Makassar, Indonesia \\ mayyadahsyuaib7@gmail.com \\ *Alamat korespondensi, Masuk: 25 Jan. 2019, Direvisi: 05 Mar. 2019, Diterima: 10 Mar. 2019
}

\begin{abstract}
ABSTRAK: Pusat perbelanjaan Mall Panakkukang Makassar saat ini tidak hanya berfungsi sebagai tempat transaksi jual beli, tetapi juga sebagai tempat rekreasi. Kecenderungan masyarakat menghabiskan lebih banyak waktu di tempat tersebut mengharuskan mereka memanfaatkan musallah sebagai sarana ibadah untuk tetap menjalankan kewajiban sebagai seorang muslim. Aksesibilitas menuju musallah pada ruang publik berperan penting terhadap pergerakan pengunjung untuk mendapatkan kemudahan, kenyamanan, keamanan dan kemandirian terutama bagi difabel. Keberadaan difabel adalah hal yang tidak bisa diabaikan, mereka memiliki hak dan kewajiban yang sama didalam hukum dan bermasyarakat. Penelitian ini bertujuan mengetahui bagaimana pemenuhan hak bagi difabel pada Musallah Mall Panakkukang Kota Makassar. Tujuan penelitian adalah untuk mengidentifikasi aksesibilitas difabel pada Mall Panakkukang Makassar. Hasil penelitian menunjukkan bahwa hanya beberapa fasilitas yang disediakan sesuai dengan standar, sehingga pengguna difabel yang memanfaatkan fasilitas Musallah dominan dari kalangan ibu Hamil dan Lansia.
\end{abstract}

Kata kunci: Pusat Perbelanjaan, Aksesibilitas, Difabel, Musallah, Standar.

\begin{abstract}
The Panakkukang Mall Makassar shopping center currently functions not only as a place for buying and selling, but also as a place for recreation. The tendency of people to spend more time in these places requires them to use mushalla as a means of worship to continue to carry out their obligations as a Muslim. Accessibility to the mushalla in public spaces plays an important role in the movement of visitors to get convenience, comfort, security and independence, especially for the disabled. The existence of diffable is something that cannot be ignored, they have the same rights and obligations in law and society. This study aims to find out how the fulfillment of the rights of persons with disabilities in Mushalla Mall Panakukang Makassar City. The purpose of this study was to identify the accessibility of disabled people in Makassar Panakkukang Mall. The results showed that only a few of the facilities provided were in accordance with the standards, so that disabled users made use of the dominant Musallah facility among Pregnant and Elderly mothers.
\end{abstract}

Keywords: Shopping centre, Accessibility, Diffable, Mushalla, Standards.

\section{PENDAHULUAN}

Kota Makassar merupakan salah satu kota besar yang terdapat di pulau Sulawesi yang terus mengalami pertumbuhan dan perkembangan. Hal ini tunjukkan dengan banyaknya berdiri pusat-pusat perbelanjaan yang didalamnya terdapat ruang publik. Ruang publik berupa lapangan, taman, tempat ibadah, pedestrian dan lain-lain. Tetapi tidak semua ruang publik di kota Makassar khususnya di Mall Panakkukang Makassar dapat diakses dengan mudah terutama oleh kaum difabel. Pemenuhan hak difabel didukung oleh Pemerintah Kota Makassar melalui Perda Nomor 6 Tahun 2013 yang menjamin hak dasar penyandang disabilitas [1] diantaranya pemenuhan sarana dan prasarana disabilitas pada ruang publik.
Kuantitas difabel cukup signifikan bagi negeri ini, namun disabilitas sebagai konstruksi sosial dan operasi sosial maka masalah disabilitas bukanlah diarahkan pada individu penyandang disabilitas, akan tetapi pada lingkungan dan bagaimana menciptakan masyarakat yang lebih terbuka atau inklusif bagi semua orang [2].

Pusat perbelanjaan Mall di Kota Makassar kini berkembang pesat tidak hanya berfungsi sebagai tempat transaksi jual beli tetapi juga sebagai tempat tujuan rekreasi, sebagai salah satu contoh adalah Mall Panakkukang Kota Makassar yang menyediakan segala kebutuhan untuk segala jenis usia dan status sosial ekonomi, hal ini sejalan dengan tulisan Eisenring [3] yang mengatakan 
bahwa Mall Panakkukang Makassar kini mulai bertransisi dari Mall keluarga menjadi surga pusat perbelanjaan yang menawarkan hampir semua barang dan untuk keperluan sehari-hari.

Bersumber dari teori Lamoreaux dan Kellner dalam artikel Eissenring [3] bahwa pusat-pusat perbelanjaan yang makin mirip dengan Disneyland, di mana semua tersedia, mulai dari sembako, makanan, hiburan, salon kecantikan, hingga sarana olahraga dan pentas kesenian, merupakan lahan subur bagi pertumbuhan budaya konsumerisme. Di dukung dengan interior Mall yang didesain sedemikian rupa sehingga Dampaknya pengunjung mall sering kali menghabiskan waktu berlama-lama berada di dalamnya. Bagi sebagian besar pengunjung khususnya kalangan muslim tentunya membutuhkan sarana ibadah (Musallah) dan diperlukan kemudahan dalam pencapaian/ aksesibilitasnya untuk semua orang.

Kenyamanan bagi difabel dalam hal aksesibilitas gedung telah diatur oleh pemerintah. Untuk aksesibilitas fisik, Departemen PU juga telah mengeluarkan Keputusan Menteri PU Nomor: 468/KPTS/1998 tanggal 1 Desember 1998 [4] tentang Persyaratan Teknis Aksesibilitas pada Bangunan Umum dan Lingkungan.

Oleh karena itu diharapkan dalam penelitian ini dilakukan pengidentifikasian aksesibilitas dalam kaitannya dengan Musallah pada Mall Panakkukang Kota Makassar dan hasilnya terhadap kehidupan difabel. Berdasarkan latar belakang yang telah di kemukakan, maka permasalahan dalam penelitian adalah (1) Bagaimana aksesibilitas bagi difabel dalam pencapaian menuju Musallah Mall Panakkukang Kota Makassar, (2) Apakah pemenuhan hak bagi difabel dalam hal sarana ibadah (Musallah) Mall Panakkukang Kota Makassar telah terpenuhi? Penelitian ini bertujuan untuk mengidentifikasi aksesibilitas difabel dalam pencapaian menuju Musallah Mall Panakkukang Kota Makassar.

\section{KAJIAN PUSTAKA Mall}

Secara umum, masyarakat mendefinisikan shopping mall itu sebagai bangunan pertokoan atau pusat perbelanjaan yang secara arsitektural menyatu, yang dibangun di atas tapak terencana, dikembangkan, dimiliki dan dikelola sebagai satu unit operasi yang berhubungan dengan lokasi, ukuran dan tipe-tipe toko-toko daerah tempat bangunan tersebut berdiri [5]. Mall Panakkukang Kota Makassar adalah salah satu dari beberapa shopping centers yang ada di Kota Makassar saat ini, dibuka pada bulan November tahun 2002, luas bangunan sekitar 84.000 M2 setinggi kira-kira 25 meter dengan konstruksi empat lantai.

Maraknya pertumbuhan mall menimbulkan perbedaan motivasi belanja dari awalnya motivasi utilitarian, kini sudah mulai berkembang pada kegiatan hedonik dengan orientasi pleasure, mencari hiburan, dan interaksi sosial. Perbedaan motivasi belanja ini, berkaitan erat dengan faktor kenyamanan akses menuju mall [6]. Hedonic shopping motives akan tercipta dengan berbelanja sembari berkeliling memilih barang sesuai selera [7].

Mengacu pada teori di atas bahwa pengunjung mall sering menghabiskan waktu yang lama di dalam mall, maka diperlukan aksesibilitas yang baik pada sarana ibadah (Musallah) untuk mendukung fungsinya sebagai ruang publik.

\section{Difabel}

Difabel merupakan istilah yang digunakan untuk penyandang cacat fisik atau masyarakat dengan kebutuhan khusus yang memiliki hambatan arsitektural dari aspek kecatatan fisik diantaranya pintu yang terlalu lebar dan sulit dibuka, tidak cukupnya ruang untuk berbelok, dan koridor yang terlalu sempit, tangga yang terlalu tinggi, lantai yang terlalu licin, pintu lift yang menutup terlalu cepat, serta tombol-tombol yang terlalu tinggi letaknya [8].

Dalam pemenuhan hak bagi Difabel seperti ibu hamil, anak-anak, lanjut usia, pengguna kursi roda, tunanetra, tunarungu, tunadaksa sering terjadi permasalahan dalam hal belum tersedianya fasilitas publik yang memungkinkan mereka hidup mandiri yang terdiri dari [9].

\section{Aksesibilitas}

Penyediaan fasilitas dan aksesibilitas dalam bangunan gedung dan lingkungan, harus dilengkapi dengan penyediaan fasilitas dan aksesibilitas dari aspek keselamatan, kegunaan, kemandirian dan perlu tersosialisasikan kepada semua komponen baik unsur penyelenggara pemerintah sehingga mampu membuat model fasilitas publik yang aksesibel bagi difabel [9]. Peraturan yang secara khusus mengatur masalah aksesibilitas ibadah di Indonesia belum disiapkan, peraturan paling penting yang terkait dengan penyandang disabilitas adalah Undang-undang No. 4 tahun 1997 tentang Penyandang Cacat [10], namun didalamnya tidak menyebutkan secara eksplisit hak-hak pendidikan, pekerjaan, rehabilitasi dan terutama aksesibilitas. Dijelaskan pula bahwa harapan untuk mencari 
fondasi aksesibilitas ibadah ke undang-undang ini tidak akan memperoleh hasil.

Accessible congerations adalah istilah yang digunakan untuk menyebut tempat ibadah yang secara fisik, komunikasi, dan sikap bisa diakses dengan mudah oleh para penyandang disabilitas, namun pada kenyataannya ide universal design yang mendorong pembangunan tempat-tempat umum untuk didesain agar bisa diakses semua orang seperti masjid sebagai media untuk 'melangit' yang tidak hanya secara spiritual tetapi terwujud secara fisik [11].

Fasilitas aksesibilitas lainnya bagi difabel yang perlu dievaluasi pada bangunan perbelanjaan adalah fasilitas parkir dan lift karena digunakan ketika individu sampai di area dan fasilitas lift untuk berpindah lantai [12]. Aksesibilitas dalam bangunan Gedung mencakup (1) Aksesibilitas area luar seperti ramp dan area parkir, (2) Aksesibilitas area dalam seperti pintu utama, ramp dan tangga, (3) Aksesibilitas fisik layanan seperti toilet, ketinggian rak, sirkulasi ruang, dan meja [13].

\section{Ruang Publik}

Ruang publik seharusnya dapat dimanfaatkan masyarakat umum tanpa kenal perbedaan sosial, ekonomi, budaya. Bahkan unsur demokratis diletakkan sebagai salah satu watak ruang publik karena ia harus dapat dijangkau (aksesibel) bagi warga dengan berbagai kondisi fisiknya termasuk para penderita cacat tubuh, ibu hamil dan lansia [14].

\section{METODE}

Penelitian ini menggunakan metode observasi lapangan dan wawancara, dan dianalisis secara deskriptif yang menjelaskan aksesibilitas Musallah di area Mall Panakkukang Makassar.

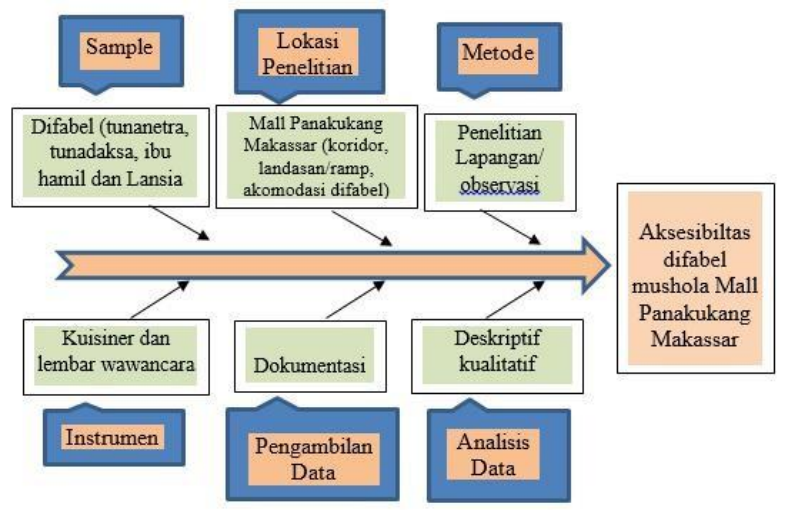

Gambar 1. Fishbone diagram
Dengan memanfaatkan instrumen penelitian berupa: kamera digital, rol meter, papan gambar, alat perlengkapan gambar, dan pedoman wawancara.

Lokasi penelitian pada Mall Panakkukang Kota Makassar yang terletak di kecamatan Panakkukang Kelurahan Masale jalan Pengayoman dan jalan Boulevard, kota Makassar Sulawesi Selatan. Waktu penelitian selama tiga (3) bulan yang dilaksanakan mulai bulan September hingga November tahun 2018.

\section{HASIL DAN PEMBAHASAN Mall Panakkukang}

Mall Panakkukang merupakan salah satu mall terbesar di Makassar. Mall ini didirikan pada tahun 2003 dan selesai pada 2006, dengan lokasi yang strategis di Kawasan Panakkukang Mall, di sekitar kawasan padat penduduk Panakkukang. Mall ini terdiri dari 4 lantai, dan 4 Koridor A, B, C, dan $\mathrm{D}$, dengan penyewa - penyewa yang sudah terkenal sebagai perusahaan besar baik skala nasional maupun internasional. Mall ini berdampingan dengan Panakkukang Square yang berjarak kurang lebih 50 meter. Saat ini mall tersebut dalam tahap renovasi dan perombakan besar-besaran, yakni banyaknya retail yang berkelas masuk, penataan dan perluasan serta penambahan gedung parkir. Begitu pula dengan restoran dan tempat makan serta cafe semua yang berskala nasional hingga internasional ada di dalam mall tersebut. Mall panakkukang juga dilengkapi dengan fasilitas seperti Musallah, bioskop, time zona, salon dan lain sebagainya.

Semakin maraknya pusat-pusat belanja yang beredar di kota Makassar membawa dampak yang sangat signifikan terhadap perilaku dan kebutuhan warga masyarakat yang memanfaatkan berbagai fasilitas tersebut demi kenyamanan para pengunjung. Pusat perbelanjaan yang ada di kota Makassar seperti MaRI, GTC, MP, M-TOS dan Mall TRANS. Pusat perbelanjaan tersebut memanjakan konsumennya dengan berbagai fasilitas yang disediakan cukup berbeda antara pusat perbelanjaan yang satu dengan lainnya.

\section{Fasilitas Musallah Mall Panakkukang Makassar}

Ruang Musallah Mall Panakkukang Makassar terletak pada lantai 2. Ketika memasuki waktu Shalat Zuhur ruang ini tidak pernah kosong dari pengunjung yang hendak beribadah, baik dari pengunjung yang melaksanakan Shalat tepat pada waktunya maupun 
tidak. Dan waktu terpadat adalah pada saat tepat memasuki waktu Shalat.

Ruang musallah terdiri atas area saf laki-laki, dan area staf perempuan, tempat berwudu yang terpisah bagi laki-laki dan perempuan, serta jalur sirkulasi yang cukup berbelok-belok.
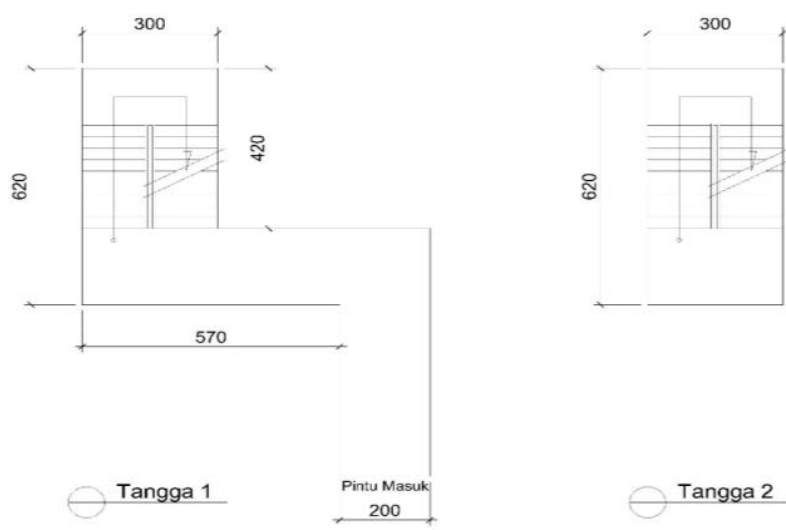

(Sumber: Digambar Kembali Peneliti, 2018)

Gambar 2. Denah sirkulasi menuju musallah

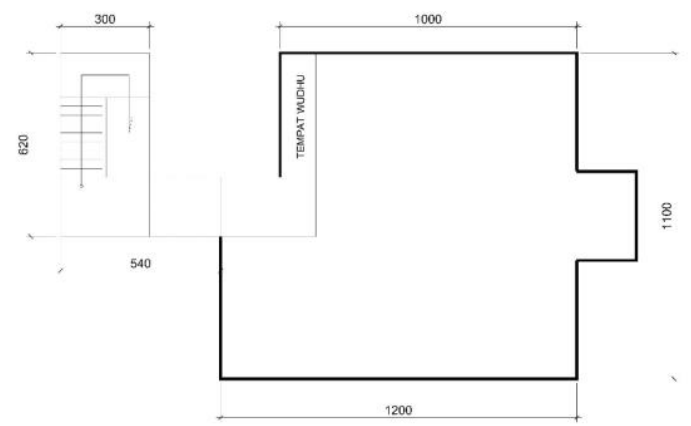

(Sumber: Digambar Kembali Peneliti, 2018)

Gambar 3. Denah Musallah mall Panakkukang

Untuk sirkulasi, pengguna Musallah masuk melalui koridor yang berukuran lebar 1,8 $\mathrm{M}$ dengan panjang koridor 7,8 $\mathrm{m}$. Jalur masuk ini merupakan satu-satunya akses yang bisa dilalui oleh pengunjung Mall, setelah itu berbelok ke arah kiri dan pengunjung akan menemukan sebuah pintu yang mengarah pada bordes tangga yang berukuran lebar $1,9 \mathrm{~m}$ dan panjang $3,8 \mathrm{~m}$. Pada area ini pengunjung akan menemukan penanda yang menunjukkan arah menuju Musallah. Berikut adalah gambar beberapa penanda di sepanjang sirkulasi menuju Musallah.

Pintu utama dan sepanjang jalur sirkulasi menuju Musallah merupakan satu-satunya akses yang menghubungkan area perbelanjaan dan Musallah, yang berarti pada area ini rentan terjadi crossing pada saat bertemunya pengguna Musallah yang masuk dan pengguna Musallah yang keluar. Terlebih pada waktu-waktu tertentu, dimana waktu beribadah cukup pendek dan umat muslim hampir bersamaan mengakses jalur tersebut.

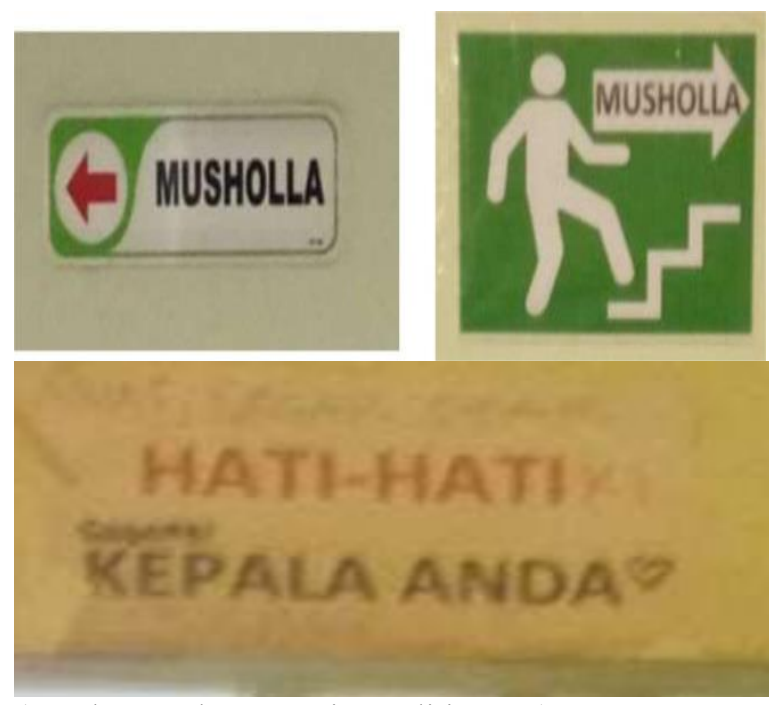

(Sumber: Dokumentasi Peneliti, 2018)

Gambar 4. Tanda arah dan rambu keselamatan pada pintu Musallah lantai 2

Dokumentasi di bawah ini menunjukkan kepadatan jalur sirkulasi Musallah pada waktu Shalat magrib.

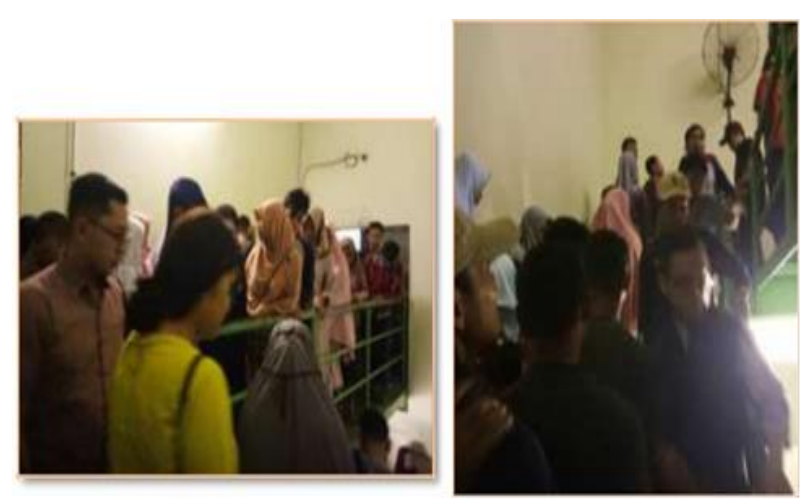

(Sumber: Dokumentasi Peneliti, 2018)

Gambar 5. Situasi kepadatan area sirkulasi pada tangga dan koridor lantai 2

\section{Aksesibilitas menuju Ruang Musallah Mall Panakkukang \\ Pintu Utama}

Pintu utama memasuki Musallah terletak pada lantai 1, dan penempatan Musallah Mall Panakkukang Makassar terletak pada lantai 2. Pintu masuk menuju Musallah berada pada lantai 1. Bagi 
kaum difabel yang berada pada lantai dasar hal ini masih mungkin diatasi dengan memanfaatkan lift.

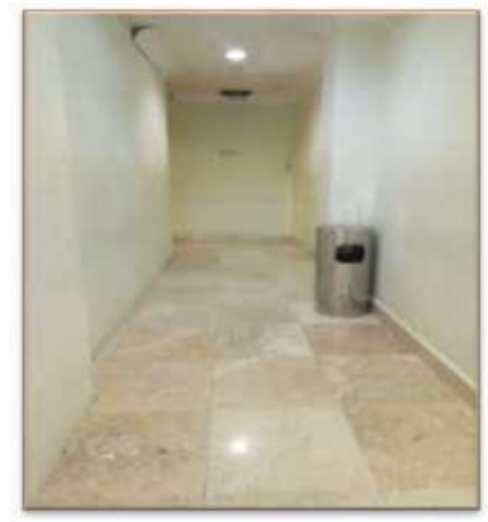

(Sumber: Dokumentasi Peneliti, 2018)

Gambar 6. Koridor/Pintu utama akses menuju Musallah

Hasil penelitian menunjukkan sirkulasi pada area pintu menuju Musallah yang masih dapat diakses bagi kaum difabel, baik yang menggunakan kursi roda maupun tidak karena berukuran lebih dari $10 \mathrm{~cm}$.

Ukuran bukaan dan ukuran tinggi pegangan pintu memasuki area bordes pada lantai 1 sudah sesuai kegunaan sebagai akses keluar masuk, berdasarkan rekomendasi peraturan pemerintah.

Pada pintu memasuki area bordes pada lantai 1 terdapat perbedaan ketinggian lantai, serta material lantai sekitar pintu berbahan licin, hal ini tidak sesuai dengan keselamatan bagi para pengunjung berdasarkan standar bangunan aksesibel.

Pintu memasuki area bordes pada lantai 1 telah disediakan ruang bebas pada kedua sisi pintu yaitu lebar $30 \mathrm{~cm}$ dan panjang $120 \mathrm{~cm}$. Hal ini telah sesuai standar ruang bebas pada sisi pintu minimum lebar $30 \mathrm{~cm}$ dan panjang $110 \mathrm{~cm}$.

Tidak disediakan rute khusus yang bisa membantu bagi tunanetra, seperti Tekstur ubin peringatan, pengarah bermotif garis-garis menunjukkan arah perjalanan dan ubin warna kuning/jingga sebagai penanda adanya perubahan situasi. Hal ini tidak sesuai dengan standar terkait jalur pemandu.

Pada bagian dinding baik sisi kiri maupun kanan tidak dilengkapi dengan handrail untuk meningkatkan kemandirian dan kemudahan bagi difabel.

Penyediaan fasilitas pintu utama pada Musallah Mall Panakkukang Makassar sebagian besar belum memenuhi aspek kemandirian, kemudahan dan keselamatan.

\section{Bordes}

Untuk mencapai Musallah pengunjung akan melalui 3 area bordes, secara keseluruhan pada ketiga area bordes ini tidak tersedia fasilitas bagi difabel berupa hand rail untuk kemandirian bagi difabel, garis pemandu untuk menunjukkan arah perjalanan, perbedaan tekstur ubin bulat untuk memberi peringatan adanya perubahan situasi di sekitarnya. Hal ini tidak memenuhi aspek kemudahan dan kemandirian bagi pengunjung Musallah difabel. Sehingga pada area bordes terdapat ketidaksesuaian dengan peraturan pemerintah No.30/PRT/M/2006 mengenai jalur pemandu.

Di bawah ini adalah kondisi eksisting area bordes yang didokumentasikan oleh peneliti.

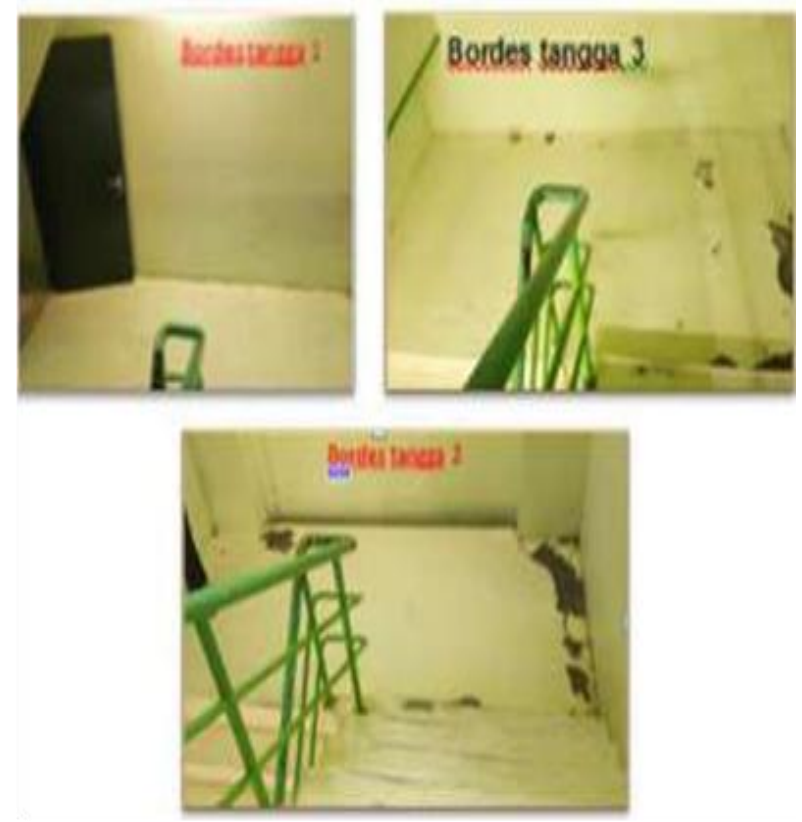

(Sumber: Dokumentasi Peneliti, 2018)

Gambar 7. Bordes tangga menuju Musallah

Akses untuk menjangkau area Musallah, pengunjung harus melewati 3 buah tangga yang masing-masing terdiri atas 8-10 anak tangga. Tangga menuju Musallah Mall Panakkukang Makassar memiliki dimensi pijakan dan tanjakan yang berukuran seragam yaitu antrede $25 \mathrm{~cm}$ dan optrede $18 \mathrm{~cm}$. Memiliki kemiringan tangga kurang dari $60^{\circ}$ tidak terdapat tanjakan yang berlubang yang dapat membahayakan pengguna. Dilengkapi dengan pegangan rambat (handrail) pada satu sisi tangga yang mudah dipegang. Bagian ujungnya berbentuk bulat yang dibelokkan dengan baik ke arah tangga. Handrail pada tangga seluruhnya memiliki ketinggian $95 \mathrm{~cm}$ dari lantai, hal ini tidak 
sesuai dengan standar yang telah ditetapkan yaitu 65-80 $\mathrm{cm}$ dari lantai. Pegangan rambat (handrail) seharusnya ditambah panjangnya pada bagian ujung-ujungnya (puncak dan bagian bawah) sepanjang $30 \mathrm{~cm}$. Hasil penelitian menunjukkan handrail tangga pada lantai 1 yang sesuai dengan standar. Dari segi bentuk profil handrail pada tangga telah sesuai dengan yang direkomendasikan. Pada setiap anak tangga belum dilengkapi nosing anti slip sesuai dengan rekomendasi PP.PU/No.30/PRT/ M/2006. Desain tangga belum sesuai dengan bentuk yang direkomendasikan oleh PP.PU/No.30/PRT/ M/2006. Gambar di bawah ini adalah desain tangga yang Manual desain bangunan aksesibel, sappk ITB direkomendasikan

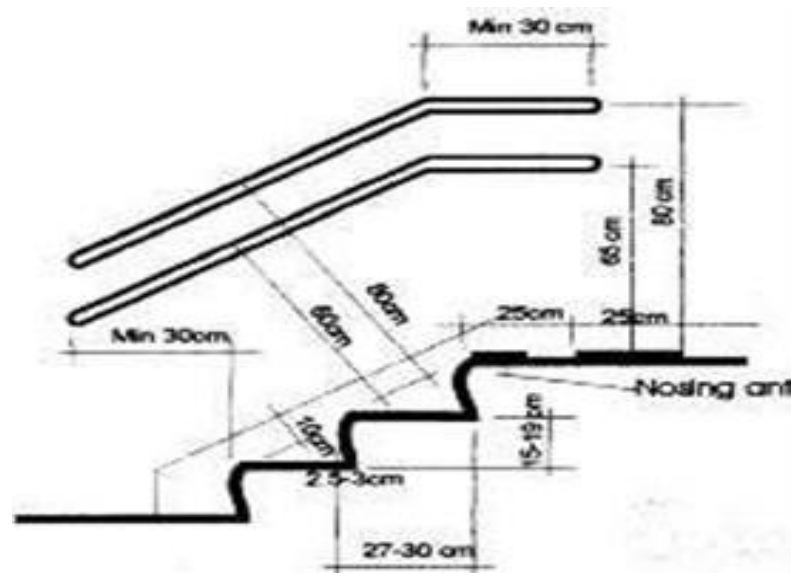

(Sumber: Dokumentasi Peneliti, 2018)

Gambar 8. Desain tipikal tangga

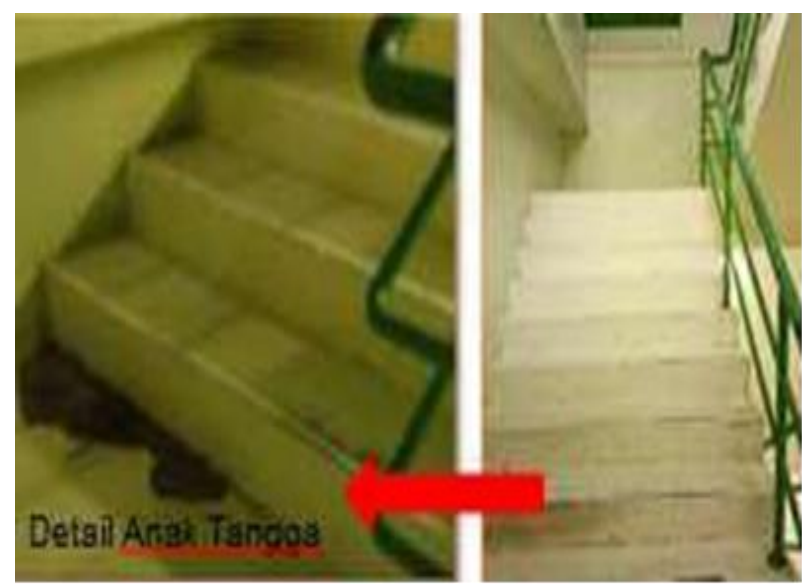

(Sumber: Dokumentasi Peneliti, 2018)

Gambar 9. Tangga akses menuju Musallah

Sebagian area tangga telah memenuhi standar aksesibel sesuai dengan peraturan pemerintah PU/No.30/PRT/M/2006, akan tetapi terdapat beberapa bagian yang belum memenuhi, seperti ukuran handrail pada bagian ujung tangga (bawah dan puncak), serta ketinggian handrail melebihi

dari standar yang ditentukan yaitu $65-80 \mathrm{~cm}$ dan belum dilengkapi nosing anti slip dan desain tangga yang belum sesuai standar, hal ini tidak memenuhi aspek kemudahan bagi pengguna fasilitas yang difabel.

\section{Lantai 2}

Sebelum memasuki pintu Musallah pada lantai 2 pengunjung akan melalui sebuah jembatan dari pelat baja dengan ukuran lebar $1,7 \mathrm{~m}$ dan panjang $4,3 \mathrm{~m}$. sebagai jalur/sirkulasi menuju pintu Musallah.

Pada jembatan pelat baja tidak disediakan rute khusus yang bisa membantu bagi tunanetra, seperti, pengarah bermotif garis-garis menunjukkan arah perjalanan dan Tekstur penanda lantai sebagai penanda adanya perubahan situasi.

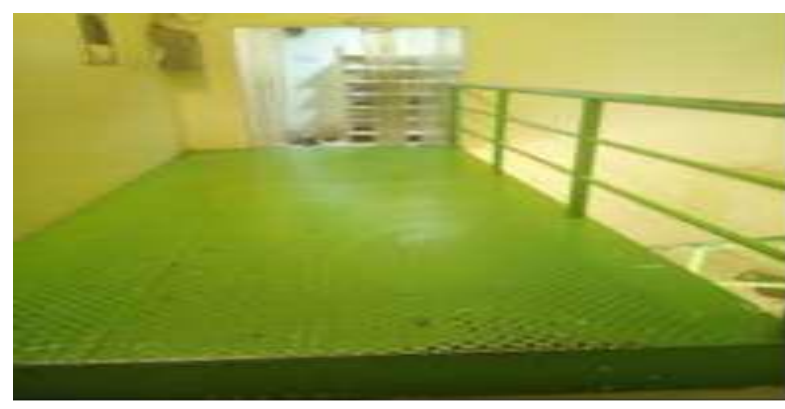

(Sumber: Dokumentasi Peneliti, 2018)

Gambar 10. Area sirkulasi

Berdasarkan prinsip desain bangunan aksesibel perbedaan ketinggian lantai setinggi $20 \mathrm{~cm}$ pada pintu Musallah pada lantai 2 tidak memenuhi aspek kegunaan dan keselamatan pengunjung berdasarkan peraturan pemerintah PU/No.30/PRT/ M/2006.

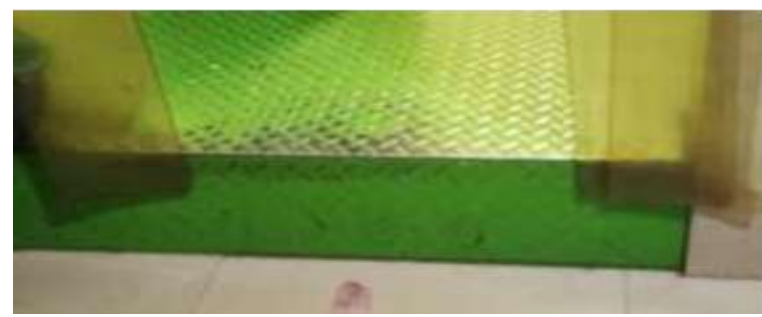

(Sumber: Dokumentasi Peneliti, 2018)

Gambar 11. Kondisi eksisting pintu

Ukuran panjang dan lebar jembatan telah memenuhi Standar ukuran dasar ruang yaitu lebar $1,2 \mathrm{~m}$ dan panjang $3 \mathrm{~m}$. Akan tetapi, ketika pengunjung Musallah dalam keadaan padat maka ukuran ini menjadi tidak aksesibel sesuai dengan 
kegunaan dan keselamatan pengunjung, berdasarkan peraturan pemerintah PU/No.30/PRT/ M/2006.

Pada area batas suci yang memisahkan area penitipan alas kaki dan ruang Shalat terdapat tangga dengan antrede $75-80 \mathrm{~cm}$ dan optrede $20 \mathrm{~cm}$. Hal ini dinilai tidak efisien bagi kelancaran sirkulasi pengunjung yang keluar/masuk dan dianggap belum memenuhi aspek kegunaan dan kemudahan bagi difabel.

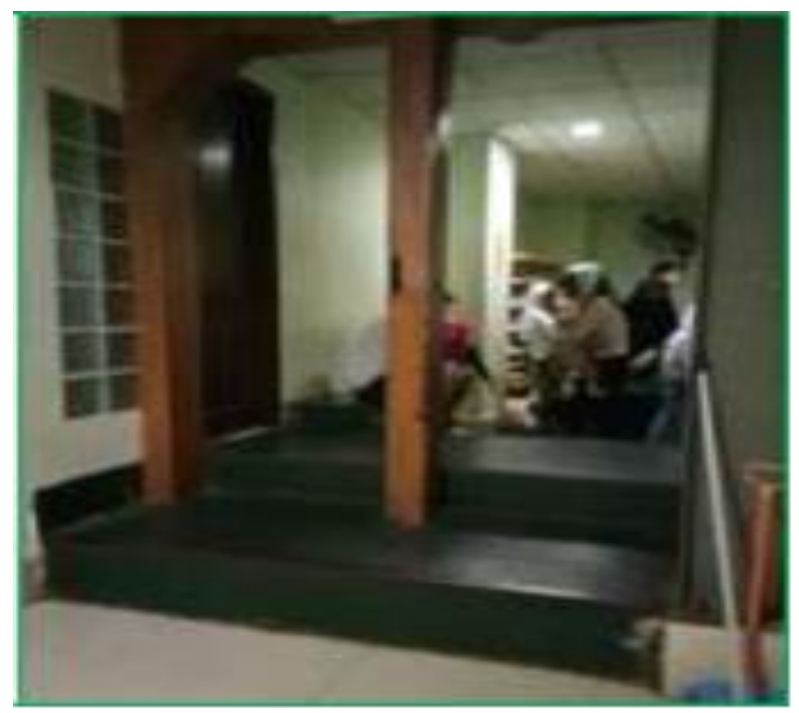

(Sumber: Dokumentasi Peneliti, 2018)

Gambar 12. Kondisi eksisting batas suci

Ketinggian kran wudu $110 \mathrm{~cm}$, tidak sesuai dengan ukuran standar yang ditetapkan yaitu maksimal $86 \mathrm{~cm}$.

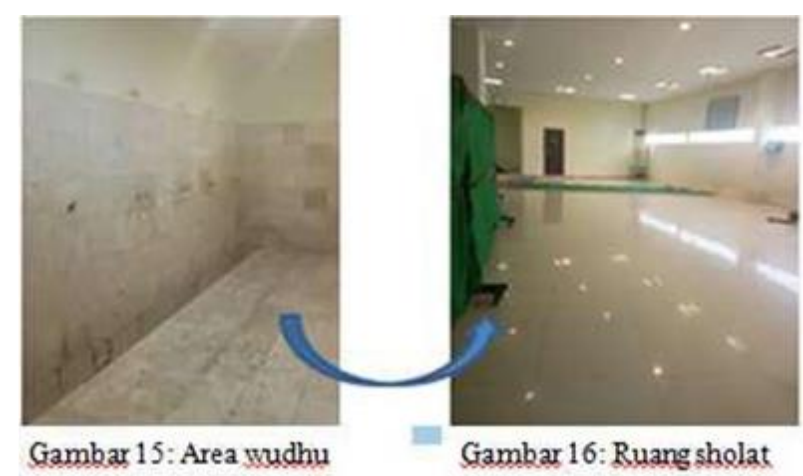

(Sumber: Dokumentasi Peneliti, 2018)

Gambar 13. Area berwudu (Kiri) area Shalat (kanan)

\section{Ruang Shalat dan Tempat Berwudu}

Pada area shalat tidak tersedia rute khusus yang dapat membantu bagi tunanetra, seperti, pengarah bermotif garis-garis menunjukkan arah perjalanan dan tekstur lantai sebagai penanda adanya perubahan situasi. Hal ini tidak sesuai dengan Permen PU/No.30/PRT/M/2006 terkait jalur pemandu. Memasuki area tempat berwudu terdapat perbedaan ketinggian lantai setinggi $40 \mathrm{~cm}$ dengan tangga berukuran antrede $25 \mathrm{~cm}$ dan optrede $20 \mathrm{~cm}$, dan tidak tersedia ram bagi pengguna kursi roda hal ini tidak memenuhi aspek kegunaan dan kemandirian bagi pengunjung. Area di depan kran wudu tidak tersedia tempat duduk bagi difabel. Area berwudu tidak tersedia pegangan rambat (handrail) untuk memenuhi aspek kemudahan dan kemandirian pengunjung. Area berwudu menggunakan material lantai berbahan licin hal ini tidak sesuai dengan kemudahan dan keselamatan bagi pengunjung.

Sebagian besar fasilitas pada ruang Shalat dan tempat berwudu belum sesuai dengan standar bangunan yang aksesibel yang telah ditetapkan peraturan pemerintah PU/No.30/PRT/M/2006.

\section{Pengunjung difabel Musallah Mall \\ Panakkukang Makassar}

Penggunaan Musallah dari kalangan difabel pada Mall Panakkukang Makassar umumnya yang terlihat hanya lansia dan ibu hamil yang masih mampu mengakses jalur/sirkulasi ke arah musallah. Pengunjung Musallah difabel lainnya, seperti pengguna kursi roda bukan tidak ada, berdasarkan hasil wawancara jalur yang cukup sulit diakses menjadikan mereka cenderung untuk memilih keluar dari Mall atau memanfaatkan Musallah pada gedung lain di luar Mall Panakkukang untuk beribadah.

Tabel berikut menunjukkan pendapat beberapa pengunjung difabel terhadap aksesibilitas Musallah Mall Panakkukang Makassar berdasarkan hasil wawancara.

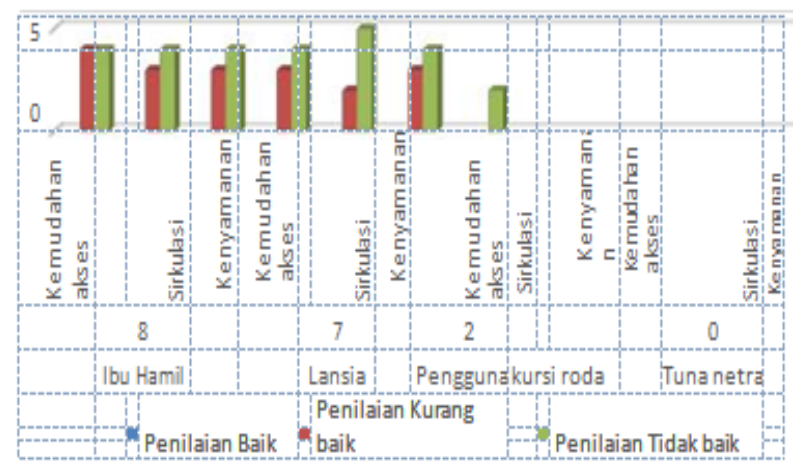

(Sumber: Analisis Peneliti, 2018)

Gambar 14. Grafik penilaian aksesibilitas difabel Mall Panakkukang 
Tabel 1. Klasterisasi penilaian Aksesibilitas Difabel Mall Panakkukang

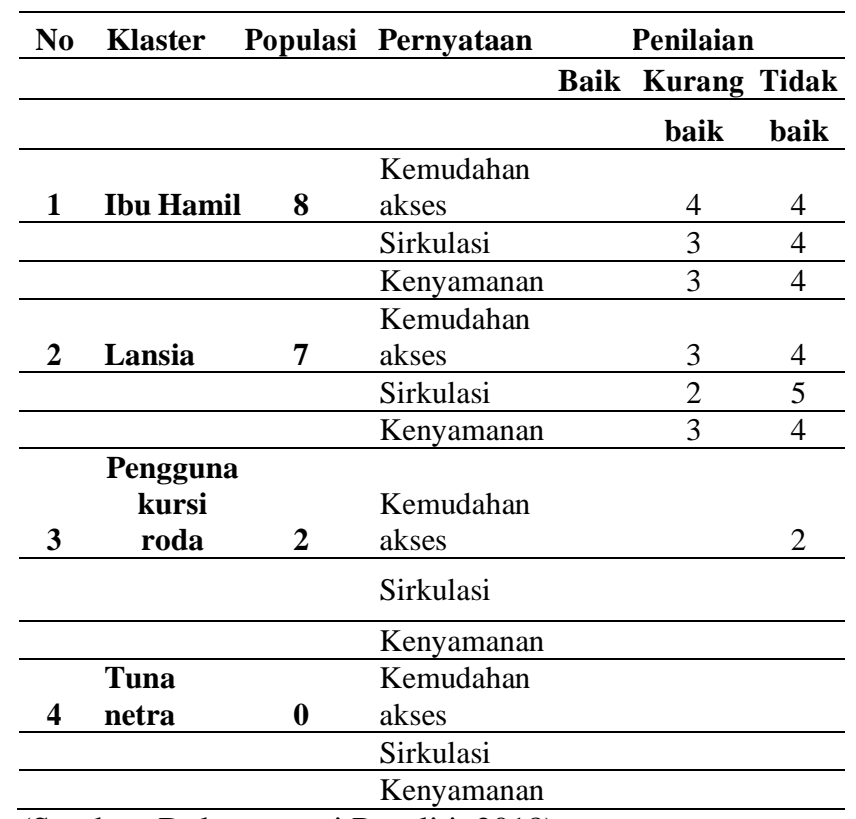

(Sumber: Dokumentasi Peneliti, 2018)

\section{KESIMPULAN DAN SARAN \\ Kesimpulan}

Ketersediaan fasilitas dan aksesibilitas bagi difabel pada Musallah Mall Panakkukang Makassar belum berjalan dengan baik hal ini dapat diketahui dari hasil identifikasi bahwa hanya beberapa fasilitas yang tersedia yang sesuai dengan standar bangunan aksesibel berdasarkan Permen PU/No.30/PRT/M/2006. Sebagian besar fasilitas yang tersedia baik pada sirkulasi maupun Musallah Mall Panakkukang Makassar belum memenuhi prinsip desain bangunan yang aksesibel yang memperhatikan terwujudnya kesamaan kesempatan dalam segala aspek kehidupan yang berasas pada keselamatan dalam suatu lingkungan terbangun, kemudahan dalam pencapaian, serta kegunaan dan kemandirian mempergunakan semua tempat atau bangunan bersifat umum tanpa membutuhkan bantuan orang lain.

Pemenuhan hak sarana ibadah bagi difabel dalam hal aksesibilitas di Mall Panakkukang Makassar belum terpenuhi dengan baik sesuai yang diharapkan. Hal ini dapat diidentifikasi melalui keengganan pengguna kursi roda mengakses Musallah Mall Panakkukang Makassar, serta tidak ditemukannya pengunjung difabel tunanetra, mereka bukan tidak ada, tetapi karena aksesibilitas yang kurang memadai dan tidak bersifat umum

\section{Saran}

Melalui data identifikasi aksesibilitas difabel pada Musallah Mall Panakkukang Makassar, diharapkan bagi pemerintah pada umumnya dan pengelola Mall Panakkukang Makassar pada khususnya, untuk memperhatikan dan merealisasikan hak-hak difabel demi mencapai kesamaan kesempatan dalam segala aspek kehidupan, dalam hal ini pemenuhan fasilitas dan aksesibilitas sarana ibadah yang bersifat umum bagi seluruh masyarakat.

\section{UCAPAN TERIMA KASIH}

Penulis mengucapkan terima kasih kepada LLDIKTI atas dukungan finansial terhadap penelitian ini, LP3M Universitas Muhammadiyah Makassar atas bimbingannya dan Pengelola manajemen Mall Panakkukang Makassar yang memberikan kesempatan untuk melakukan penelitian.

\section{DAFTAR PUSTAKA}

[1] Makassar PK (2013) Peraturan Daerah Nomor 6 Tahun 2013 Tentang Pemenuhan Hak-Hak Penyandang Disabilitas.

[2] Thohari S (2014) Pandangan Disabilitas dan Aksesibilitas Fasilitas Publik bagi Penyandang Disabilitas di Kota Malang. Indonesian Journal of Disability Studies Vol 1, Issue 1: pp. 27-37.

[3] Eisenring TSS (2016) Studi Metaforis Lingkungan "Sakral" Konsumerisme, Kasus Mal Panakkukang Makassar: Evaluasi terhadap Paradigma Katedral Konsumsi: Makassar.

[4] Umum MP (2006) Peraturan Menteri Pekerjaan Umum Nomor 30 Tahun 2006 Tentang Pedoman Teknis Fasilitas dan Aksesibilitas pada Bangunan Gedung dan Lingkungan.

[5] Sugianto H, Setyowati E, Hardiman G (2012) Shopping Mall di Kota Pekalongan (dengan Penekanan Desain Arsitektur Post Modern). Imaji, Vol.1, issue 6: pp. 1109-1116.

[6] Natalia TW, Kusuma HE (2018) Hubungan Akses Menuju Mall dan Motivasi Berbelanja Kelompok Usia Muda Dewasa Muda di Kota Bandung. Geoplanart Vol 2, Issue 1: pp. 48-56.

[7] Kosyu DA (2014) Pengaruh Hedonic Shopping Motives terhadap Shopping Lifestyle dan Impulse Buying (Survey pada Pelanggan Outler Stradivarius di Galaxy Mall Surabaya). Jurnal Administrasi dan Bisnis Vol 14, Issue 2: pp. $1-7$.

[8] Firdaus F, Iswahyudi F (2010) Aksesibilitas dalam Pelayanan Publik untuk Masyarakat dengan Kebutuhan Khusus. Jurnal Borneo Administrator Vol 6, Issue 3: pp. 1-16. 
[9] Mujimin WM (2007) Penyediaan Fasilitas Publik yang Manusiawi bagi Aksesibilitas Difabel. Dinamika Pendidikan Vol 1, Issue XIV: pp. 60-75.

[10] Undang-undang No. 4 tahun 1997 tentang Penyandang Cacat.

[11] Maftuhin A (2014) Aksesibilitas Ibadah bagi Difabel, Studi atas Empat Masjid di Yogyakarta. Inklusi Vol. 1, Issue 2: pp. 249-268.

[12] Thohari S (2014) Pandangan Disabilitas dan Aksesibilitas Fasilitas Publik bagi Penyandang Disabilitas di Kota Malang. Indonesian Journal of Disability Studies Vol 1, Issue 1: pp. 27-37.

[13] Arumsari D, Krismayani I (2018) Analisis Aksesibilitas Gedung Perpustakaan Universitas Brawijaya oleh Mahasiswa Difabel. Jurnal Ilmu Perpustakaan, Vol 7, Issue 3: pp. 201-210.

[14] Putri G, Hapsari (2011) Aksesibilitas Difabel dalam Ruang Publik. Skripsi Jurusan Sosiologi Universitas Sebelas Maret, Surakarta.

C 2019 the Author(s), licensee Jurnal LINEARS. This is an open access article distributed

under the terms of the Creative Commons Attribution License

(http://creativecommons.org/licenses/by/4.0) 